\title{
Marker-assisted pyramiding of resistance loci to grape downy mildew
}

\author{
Luciano Saifert(1), Fernando David Sánchez-Mora(2), Wilson Taybar Assumpção(3), \\ Jean Alberto Zanghelini(4), Renan Giacometti(3), Eduardo Irineu Novak ${ }^{(3)}$, Lírio Luiz Dal Vesco ${ }^{(3)}$, \\ Rubens Onofre Nodari(1), Rudolf Eibach ${ }^{(5)}$ and Leocir José Welter ${ }^{(3)}$
}

\begin{abstract}
(1)Universidade Federal de Santa Catarina (UFSC), Departamento de Fitotecnia, Campus Florianópolis, Rodovia Admar Gonzaga, no 1.346, Itacorubi, CEP 88034-001 Florianópolis, SC, Brazil. E-mail: lucianosaifert@hotmail.com, rubens.nodari@ufsc.br (2)Universidad Técnica de Manabí, Facultad de Ingeniería Agronómica, Campus Experimental La Teodomira, Km 13 1/2, Vía Santa Ana, Manabí, Ecuador. E-mail: fdsanchez@utm.edu.ec ${ }^{(3)}$ Universidade Federal de Santa Catarina (UFSC), Departamento de Ciências Naturais e Sociais, Caixa Postal 101, CEP 89520-000 Curitibanos, SC, Brazil. E-mail: taybar@gmail.com, re.n.an@hotmail.com, eduardoinovak@gmail.com, lirio.luiz@ufsc.br, leocir.welter@ufsc.br ${ }^{(4)}$ Universidade do Estado de Santa Catarina, Centro de Ciências Agroveterinárias, Avenida Luiz de Camões, no 2.090, Conta Dinheiro, CEP 88520-000 Lages, SC, Brazil. E-mail: jean.zan@hotmail.com ${ }^{(5)}$ Julius Kühn-Institut, Institute for Grapevine Breeding, Geilweilerhof, 76833 Siebeldingen, Germany. E-mail: rudolf.eibach@julius-kuehn.de
\end{abstract}

Abstract - The objective of this work was to use a marker-assisted selection for pyramiding the resistance loci Rpvl and Rpv3.1 in grapevine (Vitis vinifera), and to evaluate their conferred resistance against Brazilian downy mildew (Plasmopara viticola) isolates. A progeny of 23 plants, segregating for the two resistance loci, was obtained by the cross between the Gf 2000-305-122 and Gf.Ga-52-42 genotypes. The progeny was genotyped with four microsatellite markers and phenotyped for resistance to $P$. viticola using a bioassay with leaf discs. Six plants containing the $R p v 1$ and $R p v 3.1$ pyramided loci were identified by the molecular analysis. Plants harboring the $R p v 1+R p v 3.1, R p v 3.1$, and Rpv1 loci showed 12.8, 30.0, and 33.1 sporangiophores per leaf disc, respectively. Plants with no resistance loci showed a dense sporulation. The phenotypic analysis of the expression of the two pyramided loci was only confirmed for four plants that showed the highest resistance level, i.e., mean value of 1.8 sporangiophores. A high-throughput method for pyramiding the Rpvl and Rpv3.1 loci was developed, which confirmed the increased resistance to $P$. viticola. The selected elite genetic material shows a high resistance to downy mildew and elevated enological potential for grapevine breeding in Brazil.

Index terms: Plasmopara viticola, Vitis vinifera, enological quality, genetic resistance to disease, grapevine breeding, quantitative trait loci.

\section{Piramidação de locos de resistência ao míldio-da-videira assistida por marcadores}

Resumo-O objetivo deste trabalho foi o emprego da seleção assistida por marcadores moleculares para piramidação dos locos de resistência Rpv1 e Rpv3.1, em videira (Vitis vinifera), e avaliar o nível de resistência conferido por eles contra isolados brasileiros de míldio (Plasmopara viticola). Uma progênie de 23 plantas, com segregação para os dois locos de resistência, foi obtida do cruzamento entre os genótipos Gf2000-305-122 e Gf.Ga-52-42. A progênie foi genotipada com quatro marcadores microssatélites e fenotipada, quanto à resistência a $P$. viticola, em discos foliares. A análise molecular identificou seis plantas com os locos Rpvl e Rpv3.1 piramidados. Plantas com os locos $R p v 1+R p v 3.1, R p v 3.1$ e Rpv1 apresentaram 12,8, 30,0 e 33,1 esporangióforos por disco foliar, respectivamente. As plantas sem locos de resistência tiveram esporulação densa. A análise fenotípica da expressão dos dois locos piramidados foi confirmada somente para quatro plantas que mostraram o maior nível de resistência, isto é, média de 1,8 esporangióforos. Desenvolveu-se uma metodologia de alto rendimento para a piramidação dos locos $R p v 1 \mathrm{e}$ $R p v 3.1$, que confirmou o aumento da resistência a $P$. viticola. O material genético superior selecionado apresenta alta resistência ao míldio e elevado potencial enológico para o melhoramento da videira no Brasil.

Termos para indexação: Plasmopara viticola, Vitis vinifera, qualidade enológica, resistência genética a doenças, melhoramento genético de videira, locos de características quantitativas.

\section{Introduction}

Brazilian viticulture occupies an area of approximately 69,096 ha, with a production of approximately 1.23 million tons of grapes (IBGE, 2016). Rio Grande do Sul state excels in the production of grapes, representing more than $50 \%$ of the domestic production, besides being the largest wine producer in
Pesq. agropec. bras., Brasília, v.53, n.5, p.602-610, May 2018 DOI: 10.1590/S0100-204X2018000500009 (c) BY This is an open-access article distributed under the Creative Commons Attribution 4.0 International License 
Brazil (Mello et al., 2013). In 2016, the State reported a production of approximately 186.4 million liters of wine. Out of this total production, 19.6 million (10.5\%) liters were produced from European grapevine varieties (Vitis vinifera), and the rest came from American and hybrid varieties (Uvibra, 2016).

One of the main constraints for the cultivation of European grapevine varieties is their high susceptibility to fungal diseases. Grapevine downy mildew, caused by the oomycete Plasmopara viticola [(Berkeley \& M.A. Curtis) Berleses \& De Toni], is the main disease of the crop in the Southern region of Brazil. When not properly controlled, it can result in losses of up to $100 \%$ of the total production. In susceptible varieties, the management of downy mildew is only possible by preventive, massive applications of several fungicides (Czermainski \& Sônego, 2004; Pereira et al., 2010). This increases the production costs, as well as the risks to human health and to the environment. Therefore, the development of new cultivars, with high genetic resistance to downy mildew and high enological quality, is essential to promote the sustainability of Brazilian viticulture.

The genetic improvement of grapevine for resistance to disease is a worldwide trend that aims to reduce the application of fungicides in the crop cultivation. American species, such as Muscadinia rotundifolia, $V$. rupestris, $V$. riparia, and $V$. berlandieri (Merdinoglu et al., 2003; Marguerit et al., 2009), and Asian species with a high degree of resistance to diseases, mainly V. amurensis (Moreira et al., 2011; Blasi et al., 2011; Schwander et al., 2012; Venuti et al., 2013), have been used in breeding programs to develop resistant cultivars.

Genetic mapping has made it possible to identify the genomic regions associated with resistance to several diseases. These studies have provided molecular markers flanking genomic regions that confer resistance to diseases (Julius Kühn-Institut, 2017), enabling the use of marker-assisted selection (MAS). The genomic regions conferring resistance to downy mildew, which are referred to as "resistance to Plasmopara viticola $(R p v)$ ", have also been mapped (Julius Kühn-Institut, 2017). The Rpvl and Rpv3.1 resistance loci are located on chromosomes 12 and 18, respectively (Merdinoglu et al., 2003; Fischer et al., 2004; Welter et al., 2007; Moroldo et al., 2008; Bellin et al., 2009; Zyprian et al., 2016). Molecular markers associated with these regions were employed in MAS for pyramiding these resistance loci (Eibach et al., 2007). The pyramiding of the resistance loci for grapevine downy mildew is a trend in many breeding programs that seek to increase the durability of genetic resistance, such as for $R p v 1$ and $R p v 3.1$ (Eibach et al., 2007), Rpv3.1 and Rpv10 (Schwander et al., 2012), and Rpv12 and Rpv3.1 (Venuti et al., 2013).

In Brazil, the use of MAS in the pyramiding of disease-resistance loci in grapevine is a very recent trend. In 2012, a grapevine breeding program was initiated at the Universidade Federal de Santa Catarina, in Curitibanos, SC. The main objective of the program is to develop new disease-resistant grapevine cultivars for the production of high-quality wine. From the beginning, the strategy was to use MAS for pyramiding loci with resistance to downy mildew and powdery mildew (Erysiphe necator). The first step was to develop breeding lines containing pyramided resistance loci, and to evaluate their response to diseases in Brazil. Despite the very promising first results (Nascimento-Gavioli et al., 2017; SánchezMora et al., 2017), it is crucial to validate the use of this technology, and to define the level of resistance that different resistance loci confer to the crop in Brazil, by using different segregating populations. This work presents an example of how conventional breeding assisted with molecular tools can contribute to this purpose, and enhance the sustainability of the wine industry in the country.

The objective of this work was to use a markerassisted selection for pyramiding the resistance loci $R p v 1$ and $R p v 3.1$ in grapevine, and to evaluate their conferred resistance against Brazilian downy mildew isolates.

\section{Materials and Methods}

The segregating population derived from the crossing between Gf 2000-305-122 and Gf.Ga-5242 genotypes. The parental donor Gf 2000-305-122, derived from a cross between VHR-3082-1-42 and 'Regent', has the Rpvl locus (Merdinoglu et al., 2003). This locus is also linked to the Runl locus, which confers genetic resistance to powdery mildew in grapevines (Barker et al., 2005). The parental donor Gf.Ga-52-42, derived from a cross between 'Bacchus' and 'Villard Blanc', has the locus Rpv3.1 (Schwander et al., 
2012). Both loci confer horizontal resistance (partial) to grapevine downy mildew (Figure 1).

Only 25 adult plants were obtained from the cross because of the very low-germination rate. After introduction in the field, two additional plants died. The population was named UFSC-2012-1. Despite the small size, it was possible to develop, from this population, breeding lines containing the pyramidedresistance loci Rpvl and Rpv3.1, and to show the effectiveness of the pyramiding against the pathogen. The 23 remaining plants were genotyped with four simple sequence repeat (SSR) markers. The DNA was isolated from desiccated leaves in silica gel $(100 \mathrm{mg})$, macerated in a Precellys homogenizer (Bertin Instruments, Montigny Le Bretonneux, Île-de-France, France) using the NucleoSpin Plant II (MachereyNagel Gmbh \& Co. KG, Düren, North RhineWestphalia, Germany) extraction kit, according to the manufacturer's recommendations. The resulting DNA was quantified with the NanoDrop spectrophotometer
(Thermo Fisher Scientific, Waltham, MA, USA), and it was subsequently diluted to $1 \mathrm{ng} \mu \mathrm{L}^{-1}$ concentration.

The plants were genotyped with four microsatellite markers, two of which flanking each of the resistance loci: the SSR markers GF18-06 (Schwander et al., 2012) and GF18-08 (Zyprian et al., 2016) were flanking the resistance locus Rpv3.1 (chromosome 18); and the SSR markers Sc34-8 and Sc35-2 (NCBI STS database accession: GF111545 and GF111546) flanked the Rpvl resistance locus (chromosome 12).

Multiplex PCR reactions were performed using the Kapa 2G kit (Kapa Biosystems Inc., Boston, MA, USA). The mix was composed of 1x Kapa Fast Multiplex Mix and four pairs of primers at 0.01 $\mu \mathrm{mol} \mathrm{L}{ }^{-1}$ concentration. The primers (5' of the primer forward) were marked with the fluorescent probes 6-FAM and VIC.

The PCR reactions were performed in a C-1000 Thermal Cycler (Bio-Rad, Hercules, CA, USA), using the following program: $94^{\circ} \mathrm{C}$ for $3 \mathrm{~min} ; 30$

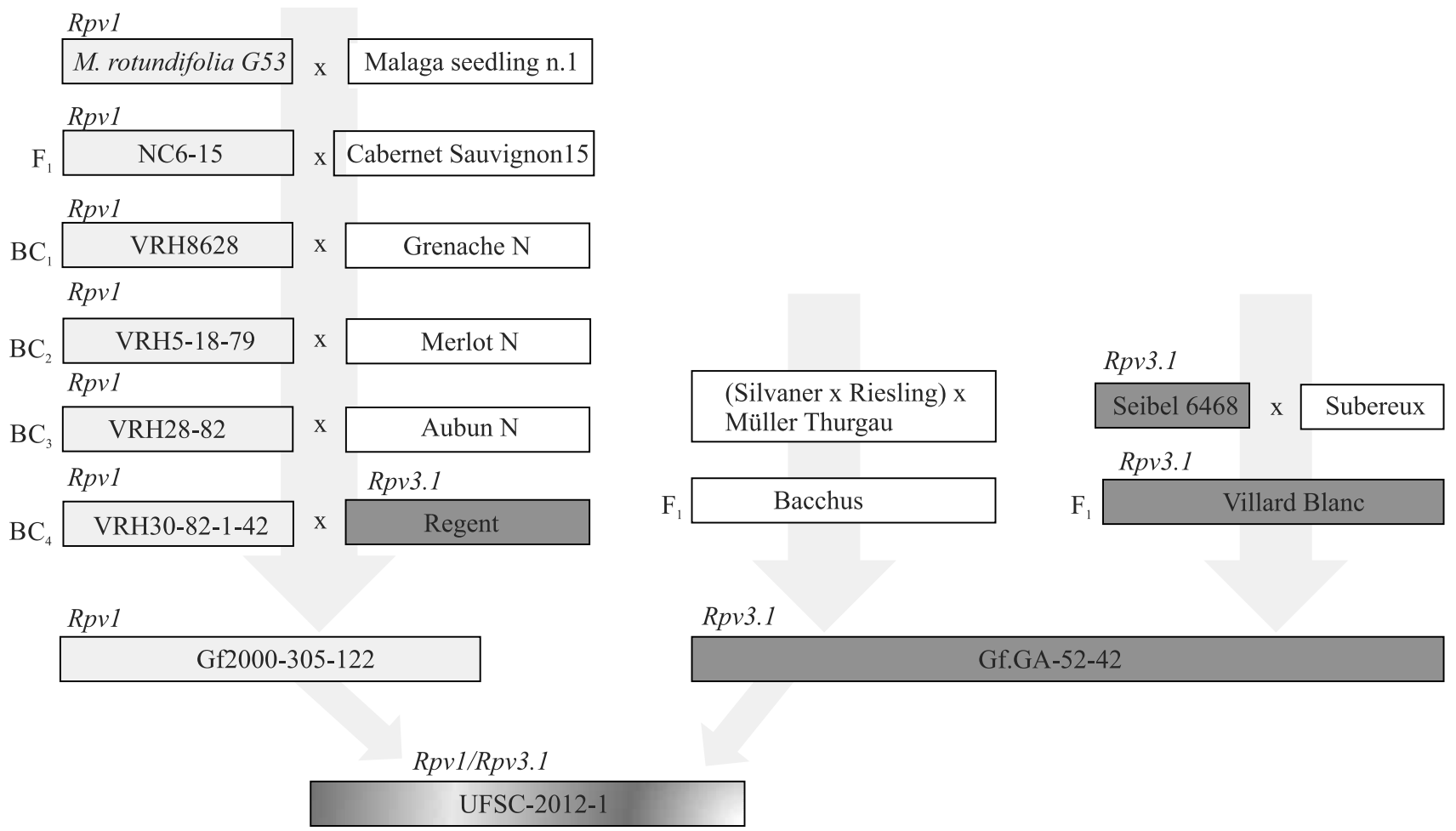

Figure 1. Pedigree of the cross population Gf 2000-305-122 × Gf.Ga-52-42. BCn represents the pseudo-backcross step at which the individual was obtained (Pauquet et al., 2001; Schwander et al., 2012; Nascimento-Gavioli et al., 2017). Arrows indicate connections between cultivars that carried the genes of resistance; light grey represents the presence of Rpvl; and dark grey, the presence of $R p v 3.1$. Predecessors are named in accordance with the Vitis International Variety Catalogue (Julius Kühn-Institut, 2017 ). 
amplification cycles at $94^{\circ} \mathrm{C}$ for $30 \mathrm{~s}, 60^{\circ} \mathrm{C}$ for $30 \mathrm{~s}$, and $72^{\circ} \mathrm{C}$ for $1 \mathrm{~min}$; and a final extension at $72^{\circ} \mathrm{C}$ for $40 \mathrm{~min}$. The PCR reaction products $(1 \mu \mathrm{L})$ were diluted in $27 \mu \mathrm{L}$ of autoclaved ultrapure water. For the sequencing run, a final volume of $10 \mu \mathrm{L}$ was used as follows: $1 \mu \mathrm{L}$ of the diluted PCR reaction, $0.5 \mu \mathrm{L}$ of the Gene Scan 600 LIZ marker (Thermo Fisher Scientific, Waltham, MA, USA), and $8.5 \mu \mathrm{L}$ formamide (Thermo Fisher Scientific, Waltham, MA, USA). Alleles were separated by capillary electrophoresis using a 3500 XL sequencer (Thermo Fisher Scientific, Waltham, MA, USA). The allele size was defined using the Gene Mapper Version 4.1 software (Thermo Fisher Scientific, Waltham, MA, USA).

Resistance assays with artificial inoculations were performed using the leaf disc methodology described by Schwander et al. (2012), with adaptations. Downy mildew sporangia were collected in a greenhouse at Universidade Federal de Santa Catarina, in the Curitibanos Campus. The $3^{\text {rd }}, 4^{\text {th }}$, and $5^{\text {th }}$ leaves from the apex to the base were collected. The leaves were disinfested with sodium hypochlorite $(1 \%$ active chlorine), followed by triple washing with autoclaved distilled water. Four leaf discs of $12 \mathrm{~mm}$ diameter were cut from each leaf in a laminar flow chamber, and positioned with the abaxial side facing up inside the autoclaved Petri dishes, over sterile filter paper moistened with autoclaved distilled water. Each leaf disc was subjected to an application of $30 \mu \mathrm{L}$ of the sporangia suspension at 50,000 sporangia $\mathrm{mL}^{-1}$. The Petri dishes were sealed with parafilm and placed in a BOD germination chamber (Lucadema, Campinas,
SP, Brazil). During the first 10 hours, the discs were kept in the dark at a constant temperature of $22^{\circ} \mathrm{C}$. After that, the program consisted of 14 hours of light, at a constant temperature of $25^{\circ} \mathrm{C}$, for seven days.

The intensity of sporulation was quantified using a stereomicroscope (Leica Microsystems, São Paulo, SP, Brazil) for counting the number of sporangiophores formed per leaf disc, after the seventh day of inoculation (Figure 2). For each genotype, the mean number of sporangiophores of the 12 analyzed leaf discs (4 discs $\times 3$ leaves) was calculated. The diagrammatic scale OIV-452 (OIV, 2009) was adapted to evaluate the level of resistance to downy mildew, in which the plants were divided into five classes, according to the number of sporangiophores: 1 , zero to five; 3 , five to twenty; 5, twenty to fifty; 7 , more than fifty; 9 , dense sporulation. The phenotypic effect of the alleles on the sporulation was evaluated by a one-way analysis of variance, and the means were compared by a Tukey's multiple comparison test.

\section{Results and Discussion}

Six plants containing the pyramided resistance alleles $R p v 1$ and $R p v 3.1$ were identified in the molecular assessments. In addition, eight plants containing only Rpv1, four plants containing only Rpv3.1, and five plants without any of these alleles were also identified (Table 1). The plant UFSC-2012-1-22 showed genetic recombination of one of the markers linked to the Rpv3.1 allele; thus, the locus, in this case, was considered absent.

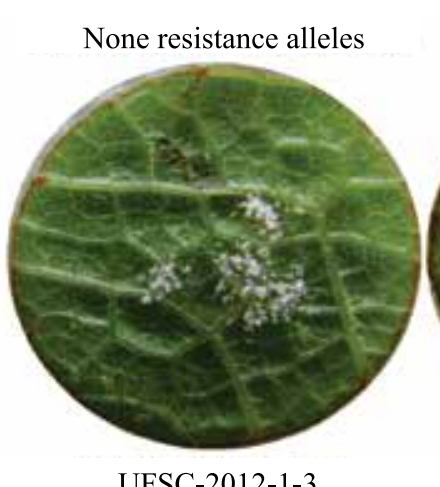

UFSC-2012-1-3

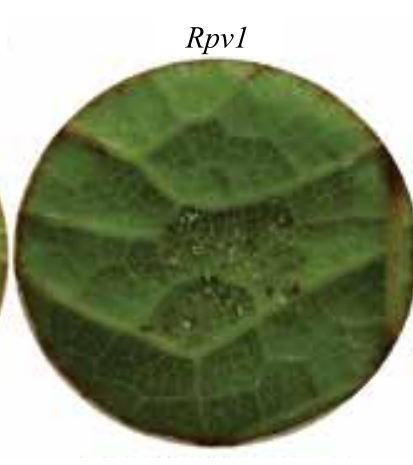

UFSC-2012-1-1

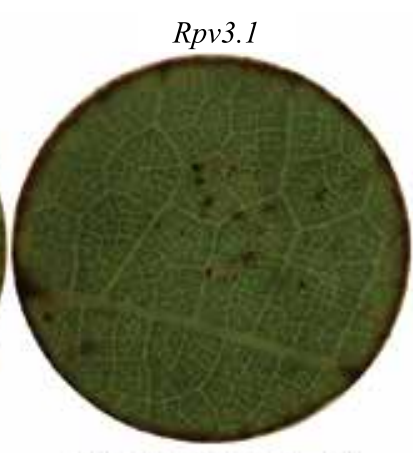

UFSC-2012-1-18

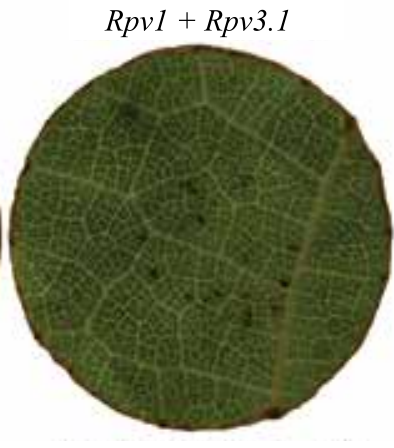

UFSC-2012-1-19

Figure 2. Symptoms of downy mildew (Plasmopara viticola), in leaf discs of plants of the UFSC-2012-1 population containing different resistance alleles. The discs had $12 \mathrm{~mm}$ diameter and were infected with a suspension of 50,000 sporangia $\mathrm{mL}^{-1}$. 
The plants that had the two combined resistance alleles had an average of 12.8 sporangiophores per leaf disc, while plants that had only one of the resistance alleles showed a mean of 31.5 sporangiophores (Table 1). Plants without the presence of any of the resistance loci were highly susceptible to the pathogen and displayed dense sporulation, making it difficult to count the sporangiophores.

Significant differences were observed in the number of sporangiophores formed on infected leaf discs of plants containing the same combination of resistance alleles (Table 1). The plants of UFSC-2012$1-15,-16,-19$, and -23 showed a very low number of sporangiophores per leaf disc (1.8 sporangiophores), and are considered the most resistant ones to the disease. This is due to the additive effect of the Rpv1 and Rpv3.1 alleles on resistance. Despite containing both resistance loci, the plants UFSC-2012-1-4 and -14 showed a high mean number of sporangiophores (26 and 44 sporangiophores per leaf disc, respectively). The analyses for these two plants were repeated to confirm the results. One hypothesis for these results would be a dual-recombination, or deletion of the genomic region in one of the resistance loci; however, dual-recombinations or deletions are rare events.

Table 1. Amplified amplicons from chromosomes 12 and 18, containing or not the resistance alleles to downy mildew (Plasmopara viticola), and plant response to artificial inoculation of the pathogen in the grapevine (Vitis vinifera) experimental population UFSC-2012-1.

\begin{tabular}{|c|c|c|c|c|c|c|}
\hline \multirow[t]{3}{*}{ Plant } & \multicolumn{4}{|c|}{ SSR markers (bp) } & \multirow[t]{3}{*}{ Alleles present } & \multirow{3}{*}{$\begin{array}{c}\text { Artificial infection } \\
\text { Mean number of } \\
\text { sporangiophores }^{(2)}\end{array}$} \\
\hline & \multicolumn{2}{|c|}{ Chromossome $12(R p v I)$} & \multicolumn{2}{|c|}{ Chromossome 18 (Rpv3.1) } & & \\
\hline & Sc34-8 & $\mathrm{Sc} 35-2$ & GF18-06 & GF18-08 & & \\
\hline & \multicolumn{4}{|c|}{ Parents of the crossing population UFSC-2012-1 } & & \\
\hline Gf.Ga-52-42 & null/223 & $245 / 253$ & $378 / 384$ & $387 / 392$ & Rpv3.1 & - \\
\hline Gf 2000-305-122 & $211 / 223$ & $232 / 245$ & $378 / 395$ & $381 / 387$ & Rpvl & - \\
\hline 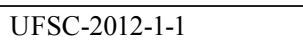 & $211 / 223$ & $232 / 253$ & 378/null & $386 /$ null & Rpv1 & $26 \pm 5$ \\
\hline UFSC-2012-1-2 & null/223 & $245 / 253$ & 378/null & 387/null & Absent & DS \\
\hline UFSC-2012-1-3 & null/223 & 245/null & 378/null & 387/null & Absent & DS \\
\hline UFSC-2012-1-4 & $211 / 223$ & $232 / 253$ & $378 / 384$ & $387 / 392$ & $R p v 1+R p v 3.1$ & $26 \pm 15$ \\
\hline UFSC-2012-1-5 & $211 / 223$ & $232 / 253$ & 378/null & 387/null & Rpv1 & $25 \pm 3$ \\
\hline UFSC-2012-1-7 & null/223 & $245 / 253$ & $384 / 395$ & $381 / 392$ & Rpv3.1 & $30 \pm 9$ \\
\hline UFSC-2012-1-8 & null/223 & 245/null & $384 / 395$ & $386 / 392$ & Rpv3.1 & $23 \pm 24$ \\
\hline UFSC-2012-1-9 & $211 / 223$ & $232 / 245$ & 378/null & 386/null & Rpvl & $>50$ \\
\hline UFSC-2012-1-10 & null/223 & 245/null & $378 / 384$ & $387 / 392$ & Rpv3.1 & $35 \pm 19$ \\
\hline UFSC-2012-1-11 & null/223 & $245 /$ null & $378 / 395$ & $381 / 387$ & Absent & DS \\
\hline UFSC-2012-1-13 & $211 / 223$ & $232 / 253$ & $378 / 395$ & $381 / 387$ & $R p v 1$ & $>50$ \\
\hline UFSC-2012-1-14 & $211 / 223$ & $232 / 253$ & $378 / 384$ & $387 / 392$ & $R p v 1+R p v 3.1$ & $44 \pm 10$ \\
\hline UFSC-2012-1-15 & $211 / 223$ & $232 / 245$ & $384 / 395$ & $381 / 392$ & $R p v 1+R p v 3.1$ & $4 \pm 3$ \\
\hline UFSC-2012-1-16 & $211 / 223$ & $232 / 245$ & $378 / 384$ & $387 / 392$ & $R p v 1+R p v 3.1$ & $1 \pm 1$ \\
\hline UFSC-2012-1-17 & $211 / 223$ & $232 / 245$ & 378/null & 387/null & Rpv1 & $47 \pm 5$ \\
\hline UFSC-2012-1-18 & null/223 & $245 / 253$ & $384 / 395$ & $387 / 392$ & Rpv3.1 & $32 \pm 10$ \\
\hline UFSC-2012-1-19 & $211 / 223$ & $232 / 245$ & $378 / 384$ & $387 / 392$ & $R p v 1+R p v 3.1$ & $1 \pm 2$ \\
\hline UFSC-2012-1-20 & $211 / 223$ & $232 / 245$ & 378/null & 387/null & Rpvl & $6 \pm 3$ \\
\hline UFSC-2012-1-21 & $211 / 223$ & $232 / 245$ & 378/null & 387/null & Rpvl & $46 \pm 4$ \\
\hline UFSC-2012-1-22 & $211 / 223$ & $232 / 253$ & $378 / 384$ & $387 /$ null & $R p v 1$ & $15 \pm 11$ \\
\hline UFSC-2012-1-23 & $211 / 223$ & $232 / 253$ & $384 / 395$ & $381 / 392$ & $R p v 1+R p v 3.1$ & $1 \pm 1$ \\
\hline UFSC-2012-1-24 & null/223 & $245 / 253$ & $378 / 395$ & $381 / 387$ & Absent & DS \\
\hline UFSC-2012-1-25 & null/223 & 245/null & 378/null & 387/null & Absent & DS \\
\hline \multirow[t]{4}{*}{ Mean of alleles present ${ }^{(1)}$} & & & & & $R p v 1+R p v 3.1$ & $12.8 \mathrm{a}$ \\
\hline & & & & & Rpv3.1 & $30.0 \mathrm{ab}$ \\
\hline & & & & & $R p v 1$ & $33.1 \mathrm{~b}$ \\
\hline & & & & & None resistance alleles & $>100.0 \mathrm{c}$ \\
\hline
\end{tabular}

${ }^{(1)}$ Means followed by equal letters do not differ, by the Tukey's multiple comparison test, at $5 \%$ probability. ${ }^{(2)} \mathrm{DS}$, dense sporulation, with uncountable sporangiophores; the numeric value of DS group in the analysis of variance was considered 100 sporangiophores per foliar disc. The analysis of variance was performed with the transformed square root of the primary values. 
Alternatively, the genetic background also affects the level of resistance to the target disease.

The effect of the combination of the resistance loci is clearly visible. In the comparison of any of the five genotypes without resistance alleles (UFSC2012-1-3) with any of the four genotypes expressing the pyramided alleles (UFSC-2012-1-19) (Figure 2), it is possible to observe that the former group displays a dense sporulation, while the latter shows no sporulation. The partial resistance conferred when the resistance loci are present alone can be observed in the plants UFSC-2012-1-1 (Rpvl) and -18 (Rpv3.1) (Figure 2). The presence and density of sporangiophores produced on artificially infected leaf discs are widely accepted as good criteria for estimating resistance to vine pathogens (Schnee et al., 2008; Schwander et al., 2012).

Taking into account the assessment through the grading scale, plants containing only one resistance loci revealed partial resistance to the disease. Plants containing the Rpvl allele displayed the highest variation in the grades, varying from 3 to 7 , with 5 as mean score. All plants containing the Rpv3.1 allele were located in score 5 . The combination of resistant loci $R p v 1+R p v 3.1$ were represented by four plants in the score 1, and two plants in the score 5. The plants without any of these resistance loci showed the highest susceptibility score (Figure 3).

There were internal variations regarding the resistant phenotype within all different combinations of the resistance loci. The phenotypic variations observed in plants carrying the same resistance alleles may be the result of the presence of other lesser-effect resistance alleles, which may contribute to resistance against the pathogen, and were also segregating in this experimental population.

Other quantitative trait loci (QTL) of lesser effects that confer resistance to downy mildew have been reported and are related to the parental forms that started the UFSC-2012-1 population (Table 2 and Figure 1).

Some QTLs associated with the parental donor Gf 2000-305-122 include a QTL designated Rpv2, which originated from $M$. rotundifolia, is located on chromosome 18 (Wiedemann-Merdinoglu et al., 2006; Bellin et al., 2009), and is also from the same donor species as for the locus Rpvl. Additionally, a QTL of lesser effect on chromosome 7 has also been previously identified (Moreira et al., 2011). Furthermore, the grape cultivar Regent, developed by the Institute for Grapevine Breeding Geilweilerhof, in Germany, is resistant to downy mildew and powdery mildew (Eibach et al., 2007; Welter et al., 2007), and has a complex pedigree formed by seven different wild species of Vitis ( $V$. aestivalis, $V$. berlandieri, $V$. cinerea, $V$. labrusca, $V$. lincecumii, $V$. riparia, and $V$. rupestris). In addition to the major effect of the QTL located on chromosome 18 (Rpv3.1), QTLs of lesser effect are located on chromosome 1 in the cultivar Regent (Heerden et al., 2014), and in chromosomes 4 (Welter et al., 2007), 9, and 10 (Fischer et al., 2004). Other seven QTLs of lesser effect have been reported in V. riparia (Marguerit et al., 2009; Moreira et al., 2011).

QTLs associated with the parental donor Gf.Ga-52-42 include individuals resulting from the cross between 'Chardonnay' and 'Bianca', in which QTLs of lesser effect against $P$. viticola were identified (Bellin et al., 2009). A QTL has been identified on chromosome 7 in 'Bianca', and a possible resistance

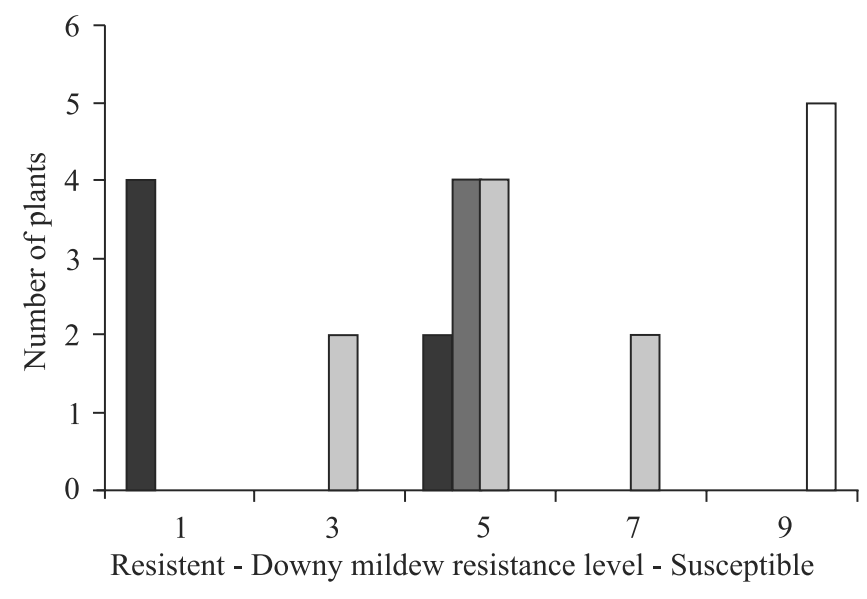

Rpv1+Rpv3.1 $\square$ Rpv3.1 $\square$ Rpv1 $\square$ None resistance alleles

Figure 3. Frequency distribution (number of plants) in each class of Plasmopara viticola infection, in a population derived from the cross Gf 2000-305-122 x Gf.Ga-52-42 $(\mathrm{N}=23)$. The intensity of sporangiophore formation was rated according to the number of sporangiophores in the following scale: 1 , zero to five; 3 , five to twenty; 5 , twenty to fifty; 7, more than fifty; 9, dense sporangiophore carpet; the sporulation was classified according to the OIV descriptor 452 (OIV, 2009) from resistant (1) to susceptible (9), using the average of four independent leaf disc tests. 
QTL has also been identified on chromosome 5 in 'Chardonnay'. 'Villard Blanc' is the parent of 'Bianca', which contains five different species of Vitis in its genome ( $V$. aestivalis, $V$. berlandieri, $V$. cinerea, $V$. lincecumii, and $V$. rupestris). 'Villard Blanc' is one of the parents of Gf.Ga-52-42. Therefore, in addition to the Rpv1 and Rpv3.1 resistance loci, identified in the UFSC-2012-1 population, other QTLs of lesser effect inherited from 'Regent', $M$. rotundifolia, or 'Villard Blanc', may be segregating in this population, thus influencing the resistance to the pathogen. The presence of different lesser-effect QTLs may be contributing to the phenotypic variance observed within the classes containing the same resistance loci.

In this context, a previous study has reported that in two populations segregating for the Rpvl and Rpv3.1 resistance alleles, the plants of the same genotype displayed variability in response to the pathogen (Sánchez-Mora et al., 2017). This variation may be attributed, in part, to the methodology employed by the authors, but also to the influence of different genetic backgrounds on the loci containing the resistance alleles. The authors of that study also stated that it was possible for some QTLs of lesser effect, or even other coding sequences segregating in the studied populations, to participate in the reaction of the plant to the pathogen. Therefore, the plants may contain the same resistance loci and have different degrees of response to the pathogen.

The results presented here are consistent with previously published results for genotypes from the cross between VHR-3082-1-42 and 'Regent', wherein it was observed that plants containing only one of the resistance loci ( $R p v 1$ or $R p v 3.1$ ) displayed intermediate resistance to the pathogen, whereas when these loci were combined, the plants showed a higher resistance to the disease (Eibach et al., 2007). Additionally, Venuti et al. (2013) reported that, when the introgression of the resistance loci of $V$. amurensis to $V$. vinifera was evaluated, the combination of the Rpvl2 and Rpv3.1 resistance alleles hindered the growth of $P$. viticola, in comparison with plants that carry only one of the alleles. Finally, the effect of the Rpv3.1 and Rpv10 alleles have been shown to confer resistance to downy mildew (Schwander et al., 2012),

Table 2. Resistance loci identified in wild Vitis species.

\begin{tabular}{|c|c|c|c|c|c|c|}
\hline Linkage group & Loci & Species/cultivar & $\begin{array}{l}\text { QTL position } \\
\text { (cM) }\end{array}$ & $\begin{array}{c}\text { Confidence } \\
\text { interval }(\mathrm{cM})^{(2)}\end{array}$ & $\begin{array}{c}\text { Flanking } \\
\text { marker }\end{array}$ & Author \\
\hline 1 & $Q T L$ & Regent & 3.73 & - & VMC9F2- cjvh & Heerden et al. (2014) \\
\hline 4 & $Q T L$ & Regent & 25.1 & $22.3-30.8$ & VMC7h3 & Welter et al. (2007) \\
\hline 5 & $Q T L$ & Chardonnay & 24.3 & $10.6-39.2$ & CS1E104J11F & Bellin et al. (2009) \\
\hline 7 & $Q T L$ & Bianca & 44.2 & $34.9-50.1$ & UDV097 & Bellin et al. (2009) \\
\hline 7 & $Q T L$ & V. riparia & 78.5 & $70.2-81.1$ & IN0006 & Moreira et al. (2011) \\
\hline 7 & $Q T L$ & M. rotundifolia & 6.4 & $0-23.3$ & VrZAG62 & Moreira et al. (2011) \\
\hline 8 & $Q T L$ & V. riparia & 26.8 & $26.0-28.1$ & VMC5G6.1 & Moreira et al. (2011) \\
\hline 9 & $Q T L$ & Regent & $-(1)$ & $27.0-36.0$ & RL14100, RA14500 & Fischer et al. (2004) \\
\hline 9 & $Q T L$ & V. riparia & - & $15.1-44.0$ & VVIO52b & Marguerit et al. (2009) \\
\hline 10 & $Q T L$ & Regent & - & - & RN181500 & Fischer et al. (2004) \\
\hline 12 & $R p v 1$ & M. rotundifolia & 10.0 & - & VMC72 & Merdinoglu et al. (2003) \\
\hline 12 & $Q T L$ & V. riparia & - & $39-51.8$ & VMC8G9 & Marguerit et al. (2009) \\
\hline 12 & $Q T L$ & V. riparia & 10.3 & $7.8-19.3$ & VMC8G6 & Moreira et al. (2011) \\
\hline 17 & $Q T L$ & V. riparia & 32.5 & $32.1-35.0$ & VVIN73;VVIQ22 & Moreira et al. (2011) \\
\hline 18 & $Q T L$ & V. riparia & 54.0 & $53.3-54.9$ & VMC2A3 & Moreira et al. (2011) \\
\hline 18 & $R p v 2$ & M. rotundifolia & - & - & - & Wiedemann-Merdinoglu et al. (2006) \\
\hline \multirow[t]{2}{*}{18} & $R p v 3.1$ & Regent & 71.2 & $66.8-101.8$ & M21300; UDV112 & Welter et al. (2007) \\
\hline & & & 1.4 & - & UDV305;UDV737 & Moroldo et al. (2008) \\
\hline \multirow[t]{4}{*}{18} & $R p v 3.1$ & Villard blanc & 80.5 & $72.1-85.5$ & VMC7F2 & Bellin et al. (2009) \\
\hline & & & 77.6 & $76.6-79.5$ & UDV305 & Bellin et al. (2009) \\
\hline & & & 17.5 & $16.4-21.5$ & GF18-06 & Schwander et al. (2012) \\
\hline & & & 14.2 & $18.7-23.4$ & GF18-08 & Zyprian et al. (2016) \\
\hline
\end{tabular}

(1)Not available. ${ }^{(2)}$ When values were recorded in more than one year or in distinct segregating populations, they were presented in intervals. 
which indicates their suitability in the pyramiding of resistance in grapevine.

In the UFSC-2012-1-15 and UFSC-2012-1-16 genotypes, with the two alleles combined, proteins were found that mainly regulate the redox metabolism, energy metabolism, stress and defense responses, and protein metabolism (Nascimento-Gavioli et al., 2017). Thus, these genotypes with the pyramided $R p v 1$ and $R p v 3.1$ alleles represent an important genetic resource for grapevine breeding programs in Brazil.

\section{Conclusions}

1. The loci Rpvl and Rpv3.1 individually confer only partial resistance to grapevine downy mildew.

2. The alleles of the two resistance loci, when combined, display an additive effect that improves the resistance level to the pathogen .

3. The elite genotypes provided in the present study shows a high resistance to downy mildew and elevated enological potential, due to its high percentage of the Vitis vinifera genome.

\section{Acknowledgments}

To Fundação de Amparo à Pesquisa do Estado de Santa Catarina (Fapesc, project number TR-20120066) and to Conselho Nacional de Desenvolvimento Científico e Tecnológico (CNPq, project number 480612/2010-2), for financial support.

\section{References}

BARKER, C.L.; DONALD, T.; PAUQUET, J.; RATNAPARKHE, M.B.; BOUQUET, A.; ADAM-BLONDON, A.-F.; THOMAS, M.R.; DRY, I. Genetic and physical mapping of the grapevine powdery mildew resistance gene, Runl, using a bacterial artificial chromosome library. Theoretical and Applied Genetics, v.111, p.370-377, 2005. DOI: 10.1007/s00122-005-2030-8.

BELLIN, D.; PERESSOTTI, E.; MERDINOGLU, D.; WIEDEMANN-MERDINOGLU, S.; ADAM-BLONDON, A.-F.; CIPRIANI, G.; MORGANTE, M.; TESTOLIN, R.; DI GASPERO, G. Resistance to Plasmopara viticola in grapevine 'Bianca' is controlled by a major dominant gene causing localised necrosis at the infection site. Theoretical and Applied Genetics, v.120, p.163-176, 2009. DOI: 10.1007/s00122-009-1167-2.

BLASI, P.; BLANC, S.; WIEDEMANN-MERDINOGLU, S.; PRADO, E.; RÜHL, E.H.; MESTRE, P.; · MERDINOGLU, D. Construction of a reference linkage map of Vitis amurensis and genetic mapping of $R p v 8$, a locus conferring resistance to grapevine downy mildew. Theoretical and Applied Genetics, v.123, p.43-53, 2011. DOI: 10.1007/s00122-011-1565-0.

CZERMAINSKI, A.B.C.; SÔNEGO, O.R. Influência das condições climáticas sobre a eficácia de fungicidas empregados para o controle do míldio em Vitis vinifera. Ciência Rural, v.34, p.5-11, 2004. DOI: 10.1590/S0103-84782004000100002.

EIBACH, R.; ZYPRIAN, E.; TÖPFER, R. The use of molecular markers for pyramidizing resistance genes in grapevine breeding. Vitis, v.46, p.120-124, 2007. DOI: 10.17660/ ActaHortic.2009.827.96.

FISCHER, B.M.; SALAKHUTDINOV, I.; AKKURT, M.; EIBACH, R.; EDWARDS, K.J.; TÖPFER, R.; ZYPRIAN, E.M. Quantitative trait locus analysis of fungal disease resistance factors on a molecular map of grapevine. Theoretical and Applied Genetics, v.108, p.501-515, 2004. DOI: 10.1007/s00122003-1445-3.

HEERDEN, C.J. van; BURGER, P.; VERMEULEN, A.; PRINS, $R$. Detection of downy and powdery mildew resistance QTL in a 'Regent' x 'RedGlobe' population. Euphytica, v.200, p.281-295, 2014. DOI: $10.1007 / \mathrm{s} 10681-014-1167-4$.

IBGE. Instituto Brasileiro de Geografia e Estatística. Levantamento sistemático da produção agrícola. 2016. Available at: <http://www.sidra.ibge.gov.br/bda/prevsaf/default. asp? $\mathrm{t}=2 \& \mathrm{z}=\mathrm{t} \& \mathrm{o}=26 \& \mathrm{u} 1=1 \& \mathrm{u} 2=1 \& \mathrm{u} 3=1 \& \mathrm{u} 4=1>$. Accessed on: June 182016 .

JULIUS KÜHN-INSTITUT. Vitis International Variety Catalogue VIVC. Available at: $<$ http://www.vivc.de $>$. Accessed on: Mar. 142017.

MARGUERIT, E.; BOURY, C.; MANICKI, A.; DONNART, M.; BUTTERLIN, G.; NÉMORIN, A.; WIEDEMANNMERDINOGLU, S.; MERDINOGLU, D.; OLLAT, N.; DECROOCQ, S. Genetic dissection of sex determinism, inflorescence morphology and downy mildew resistance in grapevine. Theoretical and Applied Genetics, v.118, p.12611278, 2009. DOI: 10.1007/s00122-009-0979-4.

MELLO, L.M.R. de; MACHADO, C.A.E. Área cultivada com videiras no Rio Grande do Sul: 2008-2012. Bento Gonçalves: Embrapa Uva e Vinho, 2013. 49p. (Embrapa Uva e Vinho. Documentos, 87).

MERDINOGLU, D.; WIEDEMANN-MERDINOGLU, S.; COSTE, P.; DUMAS, V.; HAETTY, S.; BUTTERLIN, G.; GREIF, C.; ADAM-BLONDON, A.-F.; BOUQUET, A.; PAUQUET, J. Genetic analysis of downy mildew resistance derived from Muscadinia rotundifolia. Acta Horticulturae, v.603, p.451-456, 2003. DOI: 10.17660/ActaHortic.2003.603.57.

MOREIRA, F.M.; MADINI A.; MARINO, R.; ZULINI, L.; STEFANINI, M.; VELASCO, R.; KOZMA, P.; GRANDO, M.S. Genetic linkage maps of two interspecific grape crosses (Vitis spp.) used to localize quantitative trait loci for downy mildew resistance. Tree Genetics \& Genomes, v.7, p.153-167, 2011. DOI: 10.1007/s11295-010-0322-x.

MOROLDO, M.; PAILLARD, S.; MARCONI, R.; FABRICI, L.; CANAGUIER, A.; CRUAUD, C.; DE BERARDINIS, V.; GUICHARD, C.; BRUNAUD, V.; LE CLAINCHE, I.; SCALABRIN, S.; TESTOLIN, R.; DI GASPERO, G.; 
MORGANTE, M.; ADAM-BLONDON, A.-F. A physical map of the heterozygous grapevine 'Cabernet Sauvignon' allows mapping candidate genes for disease resistance. BMC Plant Biology, v.8, art.66, 2008. DOI: 10.1186/1471-2229-8-66.

NASCIMENTO-GAVIOLI, M.C.A.; AGAPITO-TENFEN, S.Z.; NODARI, R.O.; WELTER, L.J.; SANCHEZ-MORA, F.D.; SAIFERT, L.; SILVA, A.L. da; GUERRA, M.P. Proteome of Plasmopara viticola-infected Vitis vinifera provides insights into grapevine Rpvl/Rpv3 pyramided resistance to downy mildew. Journal of Proteomics, v.151, p.264-274, 2017. DOI: 10.1016/j. jprot.2016.05.024.

OIV. Organization Internationale de la Vigne et du Vin. Compendium of International Methods of Wine and Must Analysis. $2^{\text {nd }}$ ed. Paris: Organization Internationale de la Vigne et du Vin, 2009. OIV descriptor 452.

PAUQUET, J.; BOUQUET, A.; THIS, P.; ADAM-BLONDON, A.-F. Establishment of a local map of AFLP markers around the powdery mildew resistance gene Runl in grapevine and assessment of their usefulness for marker assisted selection. Theoretical and Applied Genetics, v.103, p.1201-1210, 2001. DOI: $10.1007 / \mathrm{s} 001220100664$.

PEREIRA, V.F.; RESENDE, M.L.V. de; MONTEIRO, A.C.A.; RIBEIRO JÚNIOR, P.M.; REGINA, M. de A.; MEDEIROS, F.C.L. Produtos alternativos na proteção da videira contra o míldio. Pesquisa Agropecuária Brasileira, v.45, p.25-31, 2010. DOI: 10.1590/S0100-204X2010000100004.

SÁNCHEZ-MORA, F.D.; SAIFERT, L.; ZANGHELINI, J.; ASSUMPCÃO, W.T.; GUGINSKI-PIVA, C.A.; GIACOMETTI, R.; NOVAK, E.I.; KLABUNDE, G.H.; EIBACH, R.; DAL VESCO, L.; NODARI, R.O.; WELTER, L.J. Behavior of grape breeding lines with distinct resistance alleles to downy mildew (Plasmopara viticola). Crop Breeding and Applied Biotechnology, v.17, p.141-149, 2017. DOI: 10.1590/1984-70332017v17n2a21.

SCHNEE, S.; VIRET, O.; GINDRO, K. Role of stilbenes in the resistance of grapevine to powdery mildew. Physiological and Molecular Plant Pathology, v.72, p.128-133, 2008. DOI: 10.1016/j.pmpp.2008.07.002.
SCHWANDER, F.; EIBACH, R.; FECHTER, I.; HAUSMANN, L.; ZYPRIAN, E.; TÖPFER, R. Rpv10: a new locus from the Asian Vitis gene pool for pyramiding downy mildew resistance loci in grapevine. Theoretical and Applied Genetics, v.124, p.163-176, 2012. DOI: 10.1007/s00122-011-1695-4.

UVIBRA. União Brasileira de Vitivinicultura. Comercialização de vinhos e derivados elaborados no RS de 2009 à 2014: mercado interno e externo - em litros. Available at: $<$ http:// www.uvibra.com.br/pdf/comercializacao2009a2014_dez.pdf $>$. Accessed on: June 252016.

VENUTI, S.; COPETTI, D.; FORIA, S.; FALGINELLA, L.; HOFFMANN, S.; BELLIN, D.; CINDRIĆ, P.; KOZMA, P.; SCALABRIN, S.; MORGANTE, M.; TESTOLIN, R.; DI GASPERO, G. Historical introgression of the downy mildew resistance gene Rpv12 from the Asian species Vitis amurensis into grapevine varieties. PLoS ONE, v.8, e61228, 2013. DOI: 10.1371/ journal.pone.0061228.

WELTER, L.J.; GÖKTÜRK-BAYDAR, N.; AKKURT, M.; MAUL, E.; EIBACH, R.; TÖPFER, R.; ZYPRIAN, E. Genetic mapping and localization of quantitative trait loci affecting fungal disease resistance and leaf morphology in grapevine (Vitis vinifera L.). Molecular Breeding 20, v.20, p.359-374, 2007. DOI: 10.1007/s11032-007-9097-7.

WIEDEMANN-MERDINOGLU, S.; PRADO, E.; COSTE, P.; DUMAS, V.; BUTTERLIN, G.; BOUQUET, A.; MERDINOGLU, D. Genetic analysis of resistance to downy mildew from Muscadinia rotundifolia. In: INTERNATIONAL CONFERENCE ON GRAPE GENETICS AND BREEDING, 9., 2006, Udine. Programme and Abstracts. Udine: ISHS, 2006.

ZYPRIAN, E.; OCHßNER, I.; SCHWANDER, F.; ŠIMON, S.; HAUSMANN, L.; BONOW-REX, M.; MORENO-SANZ, P.; STELLA GRANDO, M.; WIEDEMANN-MERDINOGLU, S.; MERDINOGLU, D.; EIBACH, R.; TÖPFER, R. Quantitative trait loci affecting pathogen resistance and ripening of grapevines. Molecular Genetics and Genomics, v.291, p.1573-1594, 2016. DOI: $10.1007 / \mathrm{s} 00438-016-1200-5$.

\footnotetext{
Received on March 14, 2017 and accepted on August 22, 2017
} 